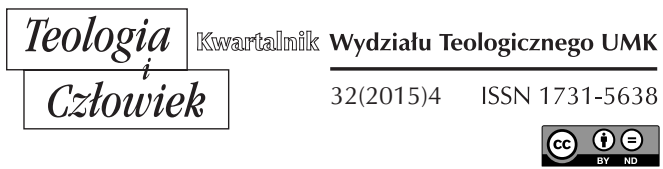

TOMASZ RÓŻAŃSKI*

\title{
Z PROBLEMATYKI PRZEMIAN I ZAGROŻEŃ WSPÓŁCZESNEJ RODZINY**
}

DOI: http://dx.doi.org/10.12775/TiCz.2015.054

Rodzina $^{1}$ nie jest tworem funkcjonującym w odosobnieniu. Przeobrażenia, które jej dotyczą, stanowią element występujących procesów społecznych. Rodzina jest nieodłącznym składnikiem społeczeństwa. Obserwuje się wzajemne oddziaływanie społeczeństwa na rodzinę oraz rodziny na społeczeństwo ${ }^{2}$.

* Tomasz Różański - doktor nauk społecznych, adiunkt w Katedrze Socjologii Edukacji i Pedagogiki Społecznej Wydziału Nauk Pedagogicznych UMK.

** Niniejszy artykuł powstał na podstawie niepublikowanych fragmentów rozprawy doktorskiej autora pt. Style życia młodzieży studenckiej a środowisko rodzinne. Studium socjopedagogiczne, która została napisana pod kierunkiem dr hab. Marii Marty Urlińskiej, prof. UMK (Wydział Nauk Pedagogicznych UMK, Toruń 2012).

${ }^{1}$ Pojęcie rodziny jest w różnoraki sposób definiowane w literaturze naukowej. Uczeni rozpatrują rodzinę m.in. w kategoriach grupy i instytucji społecznej (por. Z. Tyszka, System metodologiczny wieloaspektowej integralnej analizy życia rodzinnego, Poznań 2001, s. 43), wspólnoty i zrzeszenia (por. F. Adamski, Rodzina. Wymiar społecznokulturowy, Kraków 2002, s. 31-32), środowiska wychowawczego (por. A. Kwak, Rodzina - formy i warunki funkcjonowania, [w:] Encyklopedia pedagogiczna XXI wieku, t. 5, red. T. Pilch, Warszawa 2006, s. 314-315).

2 A. Prusik, Przeobrażenia rodziny na przestrzeni wieków, „Szkice Humanistyczne” 2006, nr 1-2, s. 124. 
Industrializacja, urbanizacja, coraz większa ruchliwość społeczna, a także przekształcenia warunków ustrojowych po II wojnie światowej stanowią blok procesów, których oddziaływaniu poddawane jest życie rodzinne. W konsekwencji można zauważyć wzrost przestrzennej ruchliwości rodzin, anonimowości jednostki i rodziny w podlegających rozszerzeniu społecznościach lokalnych ${ }^{3}$. Jak podaje Anna Kwak: „Rodzina staje się coraz bardziej zamknięta, odizolowana od najbliższego otoczenia społecznego. Następuje wzrost indywidualizmu i wolności osobistej członków rodziny, upowszechniają się seksualne kontakty przedmałżeńskie i pozamałżeńskie, liberalizują poglądy dotyczące pracy zawodowej kobiet-mężatek. Kierunki dokonujących się przemian przebiegają nie tylko w sferze poglądów na znaczenie i charakter związku małżeńskiego, ale dotykają również struktury i funkcji rodziny"4.

W opracowaniach ONZ przyczyny przemian dokonujących się $\mathrm{w}$ rodzinie podzielono na dwie grupy: do pierwszej zaliczono procesy w pełnym tego słowa znaczeniu - społeczne i zewnętrzne (przekształcenia struktury społecznej i zmiany funkcji społecznych), do drugiej - procesy indywidualne i wewnętrzne (przemiany w obrębie funkcji rodziny i przekształcenia w strukturze jej potrzeb) ${ }^{5}$.

Zbigniew Tyszka charakteryzuje przemiany rodziny w kontekście szerszych przeobrażeń społeczeństwa, uwzględniając przy tym trzy główne stadia $\mathrm{w}$ jego rozwoju: społeczeństwo preindustrialne, industrialne i postindustrialne ${ }^{6}$.

W epoce preindustrialnej, z charakterystyczną dla niej stabilną, stosunkowo sztywną strukturą społeczną oraz wolnym tempem przemian społeczno-kulturowych, ukształtował się typ tzw. rodziny klasycznej. Była to tradycyjna rodzina patriarchalna, w znacznym stopniu podporządkowana władzy ojcowskiej. Znamienne dla tego okresu niewielkie warsztaty produkcyjne stanowiły własność rodziny (lub jej „głowy”); obsługiwały je osoby wchodzące w skład rodziny pod kierunkiem ojca (męża). Role rodzinne i produkcyjne, $\mathrm{w}$ znacznej mierze ze sobą powiązane, należało

\footnotetext{
3 A. Kwak, Rodzina i jej przemiany, Warszawa 1994, s. 27.

4 Tamże.

5 F. Adamski, dz. cyt., s. 141-142.

${ }^{6}$ Z. Tyszka, Rodzina we współczesnym świecie, Poznań 2002, s. 13-19.
} 
rygorystycznie wypełniać; interes rodziny przeważał nad indywidualnym interesem jej członków. Rodzina spełniała głównie funkcję ekonomiczną i opiekuńczo-socjalizującą, nadawała również status społeczny wchodzącym w jej skład osobom. Przyczyniało się to do zachowania dużej spójności rodziny oraz dominacji stosunków materialno-rzeczowych nad osobistymi, w konsekwencji sprzyjało utrzymywaniu się rodziny wielopokoleniowej. Jej funkcjonowanie silnie regulowane było przez normy religijne i obyczajowe. Rodzina w epoce preindustrialnej wykazywała zdecydowanie instytucjonalny charakter.

W XIX i XX wieku rodziny uległy znacznym przeobrażeniom nie tylko pod wpływem industrializacji i spowodowanej przez nią urbanizacji, ale także wzmożonej ruchliwości społecznej. Przyczynił się do tego również dynamiczny rozwój nauki i oświaty. Tworzone masowo zakłady przemysłowe zaczęły wypierać przydomową produkcję rodzinną, znacznie przekształcając ekonomiczne podłoże funkcjonowania rodziny. Nastąpiło osłabienie więzi w obrębie szerszej familii, a z czasem także w obrębie rodziny dwupokoleniowej. Redukcji uległy regulatory zachowań rodzinnych i pozarodzinnych, zmieniła się również treść wielu regulatorów. W rezultacie uformował się nowy model rodziny. W okresie zaawansowanego społeczeństwa przemysłowego przyjął on formę rodziny dwupokoleniowej, będącej w posiadaniu odrębnego mieszkania oraz prowadzącej osobne gospodarstwo domowe; w rodzinie takiej zawodowo pracował nie tylko mąż, ale często także żona. Dominującą stała się rodzina nieprodukcyjna, opierająca się przede wszystkim na podstawach nieekonomicznych. Nastąpił wzrost wewnątrzrodzinnej tolerancji oraz akceptacja egalitaryzmu w rodzinie (zwłaszcza małżeńskiego). Instytucjonalny wymiar rodziny został ograniczony w porównaniu z rodziną okresu preindustrialnego.

$\mathrm{Z}$ epoką postindustrialną wiążą się dalsze zmiany w obrębie życia i funkcjonowania rodzin. Znamienne dla społeczeństw postindustrialnych są takie zjawiska, jak: zmniejszenie udziału sektora produkcyjnego w gospodarce; wzrost znaczenia sektora usług materialnych i niematerialnych; stopniowa redukcja pracy fizycznej na rzecz powiększania się sfer pracy umysłowej; wzrost liczby uczonych i instytucji naukowych; automatyzacja; rozwój międzynarodowych instytucji produkcyjnych i usługowych; wzmożona ruchliwość przestrzenna ludności; radykalne przeobrażenia struktury społeczeństw; znaczna liberalizacja regulatorów życia społecznego; nasila- 
jąca się autonomizacja jednostek. Istotną cechą epoki postindustrialnej jest to, iż autonomizacja oraz tendencje wolnościowe występują tu nie tylko w obszarze życia publicznego, ale pojawiają się także w sferze prywatnej, przejawiając się w stylu życia jednostek i rodzin. Do charakterystycznych dla rodziny epoki postindustrialnej zjawisk (i procesów) należy zaliczyć: wzrost zatrudnienia kobiet nie tylko ze względów ekonomicznych (np. samorealizacja); egalitaryzację wewnątrzrodzinną; dyferencjację norm i wartości u poszczególnych osób wchodzących w skład rodziny; stopniową marginalizację wartości tradycyjnych ( $\mathrm{w}$ tym również wartości rodzinnych); autonomizację poszczególnych członków rodziny; indywidualizację form aktywności podejmowanych w rodzinie; osłabienie spójności rodzin; narastanie konfliktów małżeńskich i znaczący wzrost rozwodów; zwiększenie się liczby osób żyjących w konkubinacie bądź w stanie wolnym; postępującą patologizację społeczną i psychospołeczną jednostek, mającą istotny wpływ na funkcjonowanie rodzin; wzrost komfortu życiowego rodzin.

Zasadnicza zmiana dotycząca funkcjonowania rodziny wiąże się z odchodzeniem od modelu, w którym funkcję jedynego żywiciela rodziny pełnił mężczyzna. Model ten przez długi czas stanowił aprobowaną formę struktury rodziny i małżeństwa. Uznawano go za najbardziej efektywną i stabilną postać rodziny ${ }^{7}$ Tenże model „wyrażał oczekiwania normatywne zawarte $\mathrm{w}$ prawie i zinternalizowane przez jednostki, odnoszące się do pozycji mężczyzny jako osoby wykonującej pracę płatną i pozycji kobiety z pracą niepłatną, której rolą jest bycie panią domu i opiekunką. Ostatnie ćwierćwiecze XX wieku przynosi zmianę w przydziale płatnej pracy ze względu na płeć i stopniowe przechodzenie do modelu większego egalitaryzmu. A zatem następuje przesunięcie oczekiwań normatywnych, zawartych w prawie i zinternalizowanych przez jednostki, w kierunku modelu z dwoma żywicielami, jednakowo ważnymi"8.

Rozwinięte społeczeństwa oferują współcześnie swym członkom szeroki zestaw dóbr związanych z życiem rodzinnym, a nierzadko także konkurencyjne cele, jakie mogą być podejmowane przez jednostkę.

7 A. Kwak, Rodzina $w$ dobie przemian. Małżeństwo i kohabitacja, Warszawa 2005, s. 19.

8 Tamże, s. 19-20. 
Człowiek w większym stopniu niż dawniej może realizować własne indywidualne cele niezależnie od interesów rodziny, do której należy. Często sama rodzina akceptuje indywidualne, pozarodzinne dążenia jednostki. Formuje się nowa hierarchia dóbr rodzinnych. Dla małżonków istotna staje się satysfakcja z życia rodzinnego i małżeńskiego. Coraz częściej brak tej satysfakcji stanowi podstawę do podejmowania działań prowadzących do rozwodu lub separacji. Za główny warunek satysfakcji małżeńskiej uważana jest długotrwała miłość. Jeśli ona wygaśnie, wielu współmałżonków czuje się upoważnionych do poszukiwania szczęścia w kolejnych związkach. O ile dawniej akcentowano przede wszystkim instytucjonalny wymiar rodziny, o tyle obecnie zaczyna coraz bardziej dominować przekonanie, że życie rodzinne i małżeńskie ma wówczas sens, jeżeli dostarcza pełnej satysfakcji współmałżonkom. Indywidualizacja wewnątrzrodzinna i dążenie do wysokiej jakości życia rodzinnego to zjawiska, które uzupełniają się i wzajemnie wzmacniają. Podstawowym dobrem stała się dla ludzi nie tyle trwałość rodziny, ile jakość życia w jej obrębie9.

Istotnym przemianom podlega socjalizacyjno-wychowawcza funkcja rodziny. Jak zauważa Zbigniew Tyszka: „Jej zakres uległ zawężeniu ze względu na obszar działania innych instytucji, ale w tym zawężonym zakresie zwiększyły się znacznie jej socjalizacyjno-wychowawcze zadania ze względu na bardziej skomplikowane warunki społeczne świata współczesnego i zwiększone wymagania edukacyjne" ${ }^{10}$. Obserwuje się wyraźną emancypację dzieci w rodzinie, zwiększeniu uległ zakres ich swobody i niezależności (dotyczy to zwłaszcza młodzieży) ${ }^{11}$. Cechą znamienną współczesnej rodziny jest koncentracja uwagi na dziecku, realizowaniu jego potrzeb, wspomaganiu rozwoju (w rodzinach prawidłowo funkcjonujących pod względem wychowawczym rodzice poświęcają dzieciom dużo czasu, starają się zapewnić im poczucie bezpieczeństwa, dbają o ich rozwój i edukację). Jednocześnie szybkie tempo przemian we współczesnym świecie (w tym także w Polsce) przyczynia się do występowania wielu zagrożeń dotyczących struktury i funkcjonowania rodziny, w tym

9 Z. Tyszka, Rodzina w świecie współczesnym - jej znaczenie dla jednostki i społeczeństwa, [w:] Pedagogika społeczna. Człowiek $w$ zmieniającym się świecie, red. T. Pilch, I. Lepalczyk, Warszawa 2003, s. 146-147.

10 Tamże, s. 148.

11 Tamże, s. 149. 
trudności w wypełnianiu funkcji wychowawczych. Problem ten pojawia się przede wszystkim $\mathrm{w}$ rodzinach niepełnych, zagrożonych patologią społeczną bądź patologicznych, w rodzinach zdezintegrowanych w sferze więzi emocjonalnej czy też w rodzinach biednych bądź zagrożonych ubóstwem. Dezintegracja życia rodzin może być ponadto skutkiem niewłaściwego wykorzystania nowoczesnych środków elektronicznych (mediów i multimediów) ${ }^{12}$.

Zdaniem Stanisława Kawuli współczesne małżeństwo i rodzina z uwagi na swój kształt i funkcjonowanie - zaczynają przypominać swego rodzaju mozaikę, w szczególności w zakresie realizowania swoich funkcji pierwotnych, przede wszystkim prokreacyjnej i emocjonalno-ekspresyjnej ${ }^{13}$. Struktury małżeńsko-rodzinne podlegają ewolucyjnym przemianom w sferze obyczajowości, zwłaszcza w społeczeństwach bardziej liberalnych, od małżeństw dwurodzicielskich, usankcjonowanych pod względem prawnym lub religijnym w wielu krajach (np. w Irlandii, Włoszech, Portugalii, Hiszpanii, Polsce), ku związkom jedno- bądź dwurodzicielskim, okresowo lub na stałe pozbawionym formalnej podstawy funkcjonowania (chodzi tutaj o tzw. związki partnerskie, konsensualne) ${ }^{14}$. Kawula przewiduje, że to, co prawdopodobnie przyjmie rzeczywisty kształt $\mathrm{w}$ ramach rodzinno-małżeńskich form życia rodzinnego w pierwszych dekadach XXI wieku, można byłoby zestawić z prognozą przedstawioną jeszcze w latach 80 . ubiegłego stulecia (ujęcie quasi-futurologiczne). Zgodnie z nią dominować będzie przede wszystkim inkluzywne (otwarte) definiowanie rodziny, małżeństwa bądź związków rodzinno-małżeńskich ${ }^{15}$, w odróżnieniu od

${ }^{12}$ J. Izdebska, Rodzina - podstawowe środowisko życia dziecka, [w:] Dziecko $w$ rodzinie $i$ w środowisku rówieśniczym. Wybrane zagadnienia i źródła z pedagogiki społecznej, red. J. Izdebska, Białystok 2003, s. 75-79.

${ }_{13}$ S. Kawula, Tendencje przemian rodziny w początkach XXI wieku, „Pedagogika Rodziny" 2007, nr 1, s. 8.

14 Tenże, Przemiany i przyszłość rodziny współczesnej, „Państwo i Społeczeństwo” 2006, nr 2, s. 11-12.

${ }_{15}$ Przykładem tego podejścia jest definicja zaproponowana przez Vanier Institute of the Family, zgodnie z którą „rodzina to jakiekolwiek połączenie dwu lub więcej osób, które złączone są więzami wynikającymi ze wzajemnej umowy, z urodzenia lub adopcji, i które razem przyjmują odpowiedzialność (obowiązki) za: 1) zapewnianie przetrwania oraz opiekę nad członkami grupy, 2) nowych członków pojawiających się przez prokreację lub adopcję, 3) socjalizację dzieci, 4) społeczną kontrolę członków grupy, 5) produkcję, 
klasycznego sposobu określania rodziny (uniwersalnego, strukturalnego i funkcjonalnego) ${ }^{16}$.

Na przemiany w zakresie definiowania rodziny, jakie dokonują się współcześnie, zwraca uwagę Tomasz Biernat. Zauważa, że pojawiające się nowe definicje rodziny zaczynają obejmować swym zakresem aktualnie upowszechniające się alternatywne formy życia małżeńsko-rodzinnego (np. związki kohabitacyjne, homoseksualne, bezdzietne $\mathrm{z}$ wyboru). Jak podkreśla uczony, ten sposób ujmowania rodziny przyczynia się do zacierania prawdy o jej naturze i powołaniu, w istocie zmienia jej tożsamość. Uwzględniając przeobrażenia sposobu definiowania rodziny, wyróżnia on następujące fazy dekonstrukcji rodziny: oddzielenie seksualności człowieka od prokreacji; oddzielenie prokreacji od rodziny i małżeństwa; oddzielenie małżeństwa od rodziny (małżeństwo stanowiło nieodłączny element rodziny zgodnie $\mathrm{z}$ jej tradycyjną definicją); zastąpienie pojęcia rodziny kategorią życia rodzinnego, jaka może przybierać różnorakie formy i treści. Następstwem rozszerzania definicji rodziny jest eliminowanie jej wymiaru instytucjonalnego. Poszerzanie to wiąże się ponadto z przenoszeniem praw przynależnych rodzinie opartej na małżeństwie innym formom życia małżeńsko-rodzinnego, określanym jako alternatywne ${ }^{17}$.

Alternatywne formy życia małżeńsko-rodzinnego stanowią „rzeczywiste układy życia, z których wiele jest aprobowanych społecznie i legalizowanych - zwykle po pewnym czasie, ex post facto - przez prawo. Ponieważ są akceptowane i legalizowane, stają się wzorami zinstytucjonalizowanymi i dają "partnerską wyłączność siebie «"18. Mogą one różnić się w zależności od warstwy społecznej, grupy etnicznej, regionu świata, kultury, religii, a także od preferencji osobistych ${ }^{19}$.

konsumpcję i dystrybucję dóbr i usług, 6) zapewnienie emocjonalności i zażyłości”, cyt. za: W. Bołoz, Przemiany rodziny we współczesnym społeczeństwie, „Homo Dei” 2009, nr 1, s. 13.

16 S. Kawula, Przemiany, s. 10.

17 T. Biernat, O przemianach definiowania rodziny $i$ ich konsekwencjach, „Społeczeństwo i Rodzina” 2009, nr 1, s. 36-37.

${ }^{18} \mathrm{~K}$. Slany, Alternatywne formy życia małżeńsko-rodzinnego $w$ ponowoczesnym świecie, Kraków 2002, s. 82.

19 Tamże. 
Alvin Toffler utrzymuje, że współcześnie liczba rodzin dwupokoleniowych wciąż zmniejsza się, wzrasta natomiast ilość innych form życia rodzinnego. Obecnie jesteśmy świadkami silnych przemian obyczajowych, które polegają m.in. na tym, że coraz więcej osób żyje samotnie, poza rodziną. Przy tym wiele $\mathrm{z}$ nich świadomie decyduje się na takie rozwiązanie. Istnieją grupy ludzi, którzy wcześniej funkcjonowali w małżeństwie, a obecnie mieszkają sami i którym często właśnie takie życie odpowiada najbardziej. Rozrost tego rodzaju grup przyczynia się do rozkwitu swoistej kultury „singli”. Upowszechniają się rozmaite związki niesformalizowane, w których partnerzy zamieszkują razem, nie przywiązując wagi do formalnoprawnych aspektów funkcjonowania związku. Pojawia się także coraz więcej par świadomie rezygnujących $\mathrm{z}$ posiadania dzieci ${ }^{20}$. Jak podaje Toffler: „W wysoko rozwiniętych krajach obserwujemy dziś niesamowitą różnorodność form rodziny: współistnieją obok siebie, jak nigdy przedtem, małżeństwa homoseksualne, komuny, grupy ludzi starszych lgnących ku sobie, by dzielić koszty utrzymania (a niekiedy również seks), skupiska plemienne wśród niektórych mniejszości etnicznych i wiele innych. Istnieją małżeństwa kontraktowe, małżeństwa-seriale [...], rodziny gromadne i najróżniejsze zbiorowiska ludzi związanych zażyłością, którzy współżyją ze sobą seksualnie lub nie, jak również rodziny, w których matka i ojciec mieszkają i pracują w dwóch różnych miastach"21.

Lucile Duberman zwraca uwagę na następujące formy życia rodzinnego, alternatywne w stosunku do tradycyjnej rodziny dwupokoleniowej: małżeństwo grupowe - group marriage (składa się z kilku kobiet i mężczyzn, którzy pozostając w związkach małżeńskich, w sposób dowolny podejmują współżycie seksualne w grupie; dzieci mają tutaj kilka matek i ojców, a relacje biologiczne nie mają większego znaczenia; panuje zasada podziału zarobków, obowiązków, zadań); rodziny wspólnotowe - communal families (tworzone są zwykle przez kilka par monogamicznych i ich potomstwo; zasada wspólnoty odnosi się do zarobków, dóbr materialnych, zadań, lecz nie dotyczy życia seksualnego); niezamężne małżeństwa unmarried marriage (składają się z osób pozostających w stanie wolnym, ale tworzących parę; nierzadko osoby te posiadają wspólny budżet); ro-

\footnotetext{
20 A. Toffler, Trzecia fala, Warszawa 1997, s. 326-328.

21 Tamże, s. 331.
} 
dziny bez dzieci z pracującymi partnerami - dual-career family without children (pary małżeńskie, które nie zamierzają mieć dzieci; zarówno mężczyźni, jak i kobiety dążą do spełnienia się w pracy zawodowej; dla kobiet macierzyństwo nie stanowi jedynej i zasadniczej formy realizacji siebie); rodziny z dziećmi z pracującymi partnerami - dual-career family with children (oboje małżonkowie pracują zawodowo, utrzymują gospodarstwo domowe, realizują zadania i nie rezygnują z posiadania potomstwa); rodziny z jednym rodzicem - one-parent family (powstają w następstwie rozwodu, śmierci współmałżonka lub niezamężnego rodzicielstwa); rodziny rekonstruowane - reconstituted family (tworzą się, gdy co najmniej jedno z małżonków wprowadza do nowego związku małżeńskiego jedno bądź więcej dzieci z poprzedniego małżeństwa) ${ }^{22}$.

Bram Buunk wyodrębnia alternatywy dla małżeństwa i alternatywy w małżeństwie. Do pierwszej grupy włącza: życie samotne (singlehood), co nie oznacza zawsze konieczności prowadzenia jednoosobowego gospodarstwa; niezamężną kohabitację (nonmarital cohabitation); komuny (communes); związki homoseksualne (homosexuality). Do alternatyw w małżeństwie zalicza: związki, w których żony pracują zawodowo (gainfully employed wives); dobrowolną bezdzietność (voluntary childlessness); seks pozamałżeński (extramarial sex) ${ }^{23}$.

Według Anny Kwak jako alternatywne formy życia rodzinnego określa się układy wzajemnych powiązań seksualnych oraz rodzinnych, które nie są usankcjonowane pod względem prawnym i/lub nie uwzględniają biologicznego rodzicielstwa. Uczona wymienia wśród nich: związki, które nie opierają się na formalnie zatwierdzonym małżeństwie (np. kohabitacje); związki oparte na prawnie usankcjonowanym małżeństwie, ale nie uwzględniające biologicznego rodzicielstwa (np. bezdzietne małżeństwa rezygnujące z posiadania dzieci); związki, które były poprzedzone wcześniejszym małżeństwem, aktualnie zawierające jedynie kryterium biologicznego rodzicielstwa (np. rodziny niepełne); rodziny oparte tylko na biologicznym rodzicielstwie (np. niezamężne macierzyństwo) ${ }^{24}$. Wyróżnione formy nie są nowe, wiele $\mathrm{z}$ nich ma swoją długą historię,

\footnotetext{
22 Za: A. Kwak, Rodzina $w$ dobie, s. 86-87.

23 Tamże, s. 87.

24 Tamże, s. 91.
} 
przeobrażeniom podlegał jedynie stosunek opinii społecznej do nich oraz zasięg i rozmiary zjawiska ${ }^{25}$.

Różnorodność alternatywnych form życia małżeńsko-rodzinnego jest współcześnie dostrzegalna, czasem wręcz eksponowana, jednakże zasadniczy typ rodziny formalnej, monogamicznej nie zanika. Stanowi ona bowiem punkt odniesienia dla innych wyodrębniających się form rodzinnych, zwłaszcza w sferze wypełniania zasadniczych funkcji rodziny, a także osiągania satysfakcji osobistych ${ }^{26}$.

Przemiany współczesnej rodziny polskiej należy rozpatrywać w szerszym kontekście uwarunkowań historycznych, politycznych i społeczno-kulturowych ${ }^{27}$. Okres po II wojnie światowej cechowała znaczna dynamika przeobrażeń dotyczących struktury i funkcjonowania rodzin w Polsce. Industrializacja, urbanizacja, rozwój oświaty, migracje społeczne, przemiany kulturowe i obyczajowe to istotne czynniki, jakie decydowały o procesach przebiegających $\mathrm{w}$ rodzinach. W etap transformacji społeczno-ustrojowej, co nastąpiło po 1989 r., polska rodzina wkroczyła bardzo osłabiona. Poprzedni system polityczny przyczynił się w znacznej mierze do degradacji ekonomicznej i dezintegracji tejże instytucji ${ }^{28}$. Po upadku reżimu komunistycznego w Polsce nasileniu uległy następujące zjawiska: „upowszechnianie liberalnych poglądów etycznych w odniesieniu do życia małżeńsko-rodzinnego, szerzenie postaw antyklerykalnych i antykościelnych, wskutek czego słabnie autorytet religii i duchownych w kształtowaniu klarownych poglądów na tematy rodzinne, wzrost aktywności ugrupowań politycznych głoszących, że rodzina jest sprawą prywatną, że dotychczas państwo prowadziło w stosunku do niej politykę nadopiekuńczą i w przyszłości pomoc rodzinie należy zmniejszyc' ${ }^{29}$. Według Leona Dyczewskiego konsekwencją występowania tych zjawisk w polskim społeczeństwie jest upowszechnianie się przekonania, że obowiązujące do tej pory reguły i formy życia rodzinnego są naruszalne i tworzą się nowe jako

25 A. Kwak, Rodzina i jej, s. 53.

${ }^{26}$ K. Slany, Definicje pojęć „małżeństwo” $i$ „rodzina” w obliczu pojawienia się alternatywnych form życia małżeńsko-rodzinnego, „Małżeństwo i Rodzina” 2002, nr 4, s. 3.

27 Z. Tyszka, Rodzina we współczesnym, s. 91.

${ }_{28}$ T. Biernat, P. Sobierajski, Młodzież wobec małżeństwa i rodziny. Raport z badań, Toruń 2007, s. 10.

${ }^{29}$ L. Dyczewski, Rodzina, społeczeństwo, państwo, Lublin 1994, s. 129. 
równorzędne do dotychczasowych. Kształtuje się opinia, że zasady i formy życia rodzinnego cechuje zmienność, tak jak wiele innych reguł życia ${ }^{30}$.

Przyczynami przeobrażeń rodziny polskiej przełomu XX i XXI wieku są przekształcenia ekonomicznych relacji pomiędzy państwem a rodziną, między rozmaitymi instytucjami a rodziną, dynamiczne przemiany na rynku pracy, zaznaczające się nierówności ekonomiczne i społeczne, a także znaczne obniżenie poczucia bezpieczeństwa socjalnego. Wymagania, jakie niesie ze sobą gospodarka rynkowa, odnoszą się do mobilności, umiejętności, kwalifikacji oraz zaangażowania w życie zawodowe. Od tych elementów w znacznym stopniu zależy pozycja społeczna, zawodowa i ekonomiczna jednostki ${ }^{31}$. Wymienione „wymagania wpływają hamująco na skłonności do zawierania małżeństw, przyczyniają się do opóźniania zakładania rodzin, rodzenia dzieci oraz osłabiają tendencję do posiadania większej liczby dzieci. Zmiany w zakresie zachowań seksualnych, możliwość planowania urodzeń, społeczne przyzwolenie na realizację życia według indywidualnych oczekiwań i potrzeb przyczyniają się do tego, że małżeństwo nie jest już jedyną formą współżycia, a rodzicielstwo sposobem samorealizacji" 32 .

Z przeglądu badań dokonanego przez Tomasza Biernata i Pawła Sobierajskiego wynika, że typową rodziną polską jest obecnie rodzina nuklearna, tj. złożona $\mathrm{z}$ dwóch pokoleń (rodziców i dzieci). Dominujący w okresie PRL-u model $2+2$ zastępowany jest w ostatnich latach modelem $2+1$. W $1998 \mathrm{r}$. wykazano ujemny przyrost naturalny w polskich miastach, a w 2002 r. odnotowano to zjawisko w skali ogólnokrajowej. Od połowy lat 90. ubiegłego stulecia Polska znajduje się w sferze zawężonej reprodukcji ludności, co oznacza, iż aktualne pokolenie matek nie jest zastępowane przez pokolenie córek. Coraz później zawierane są związki małżeńskie, co nierzadko stanowi następstwo odraczania decyzji o poczęciu pierwszego dziecka (obecnie najwięcej dzieci rodzą kobiety w wieku 25-29 lat, podczas gdy na początku lat 90 . XX w. były to kobiety pomiędzy 20. a 24. rokiem życia). Odkładanie decyzji dotyczącej poczęcia dziecka wiąże się często z przedłużającym się etapem kształcenia i późniejszym

\footnotetext{
30 Tamże, s. 130.

31 A. Kwak, Rodzina - formy, s. 320.

32 Tamże.
} 
wkraczaniem w dorosłe życie (zdobycie wykształcenia, uzyskanie pracy), niekorzystną sytuacją ekonomiczną, ale może również wynikać ze zmiany stosunku ludzi do posiadania potomstwa (w obecnych czasach dziecko coraz częściej rywalizuje w innymi wartościami, nie jest już naturalną konsekwencją małżeństwa, co przyczynia się do redukcji prokreacji). Inny problem stanowi stopniowe osłabianie trwałości rodziny w Polsce (o ile w 1993 r. było 27,9 tys. rozwodów, o tyle w 1998 r. ich liczba wzrosła do 45,2 tys.). Od 1993 r. zauważa się w naszym kraju przewagę małżeństw rozwiązanych nad zawartymi (z rozmaitych powodów, $\mathrm{w}$ tym również śmierci współmałżonka). Zwiększa się liczba związków o charakterze nieformalnym (pary żyjące bez ślubu). Liczną grupą są także samotni rodzice, którzy w następstwie różnych okoliczności samotnie zajmują się wychowywaniem dzieci (śmierć współmałżonka, rozwód, decyzja o życiu w pojedynkę). Wzrasta ponadto liczba gospodarstw jednoosobowych, tworzonych przez osoby, które nie planują bądź z różnorakich powodów odraczają wstąpienie w związek małżeński ${ }^{33}$.

Sytuacja rodziny na początku XXI wieku może budzić więc wiele obaw. Maleje liczba zawieranych małżeństw przy jednoczesnym upowszechnianiu się tzw. związków bez zobowiązań, umożliwiających większą swobodę w realizacji indywidualnych dążeń. Zwiększa się ilość rozwodów, które często traktowane są jako skuteczny sposób rozwiązywania konfliktów. Współczesna rodzina staje się coraz mniejsza, a dziecko przestaje być najistotniejszym celem życia rodzinnego. Zauważalne jest $\mathrm{w}$ rodzinach zbytnie nastawienie na zaspokajanie potrzeb materialnych dzieci kosztem ich potrzeb emocjonalnych. Wzrastająca marginalizacja kontaktów emocjonalnych i społecznych oddziałuje w sposób negatywny na rozwój osobowości i socjalizację ludzi młodych. Zanik więzi rodzinnych oraz ograniczony kontakt z dorosłymi powoduje, że dzieci są coraz bardziej narażone na rozmaite patologie życia społecznego ${ }^{34}$.

Podsumowując niniejsze rozważania, należy zauważyć, że rodzina to podstawowy i trwały składnik społecznej organizacji, pojawiający się

${ }^{33}$ T. Biernat, P. Sobierajski, dz. cyt., s. 14-16.

${ }^{34}$ N. Pikuła, Aktualna sytuacja $i$ tendencja zmian $w$ rodzinie XXI wieku, [w:] Wybrane zagadnienia pedagogiki rodziny, red. A. Błasiak, E. Dybowska, Kraków 2010, s. 65-67. 
u wszystkich znanych ludów na różnych etapach ich rozwoju. Naznaczona jest ona zawsze kontekstem historycznym i kulturowym ${ }^{35}$, dlatego też - jak podkreśla Wojciech Bołoz - „ciągłości istnienia tej instytucji towarzyszy jej ustawiczna ewolucja: na przestrzeni wieków zmieniają się formy rodziny i pełnione przez nią funkcje. Ta zdolność adaptacyjna rodziny świadczy, że jest ona instytucją nieodzowną tak dla poszczególnych osób, jak i całych społeczności i że powinna być postrzegana jako gwarant trwałości gatunku ludzkiego"36.

Streszczenie. Niniejszy artykuł poświęcono problematyce przemian i zagrożeń współczesnej rodziny. Punktem wyjścia było scharakteryzowanie przeobrażeń rodziny w kontekście szerszych przemian społeczeństwa, uwzględniające trzy stadia w jego rozwoju - społeczeństwo preindustrialne, industrialne i postindustrialne. Następnie wskazano na przekształcenia w obrębie socjalizacyjnej i wychowawczej funkcji rodziny. Kolejny poruszony problem dotyczył zmian, jakie dokonują się obecnie w zakresie definiowania rodziny. W konsekwencji, w dalszej części artykułu zwrócono uwagę na alternatywne formy życia rodzinnego. Dopełnieniem podjętych rozważań było omówienie przemian współczesnej rodziny polskiej oraz zaprezentowanie wyników badań odnoszących się do tej problematyki. Wskazano również na zagrożenia dzisiejszej rodziny jako konsekwencje dokonujących się transformacji.

Słowa kluczowe: rodzina; alternatywne formy życia rodzinnego; wychowanie $\mathrm{w}$ rodzinie; zmiana społeczna.

Abstract. The Issue of Changes and Threats to the Modern Family. This article is devoted to the issues of changes and threats to the modern family. The starting point was to characterize the transformation of the family in the context of broader transformation of society, here the three stages of society development were taken into account - pre-industrial, industrial and postindustrial society. Then, the transformations of socializing and educational functions of the family were pointed out. Another raised issue was the ongoing alterations of the definition of the family. Consequently, the attention was drawn to the alternative forms of family life. To complement the considerations, the changes of the modern Polish family were discussed and the results of the related studies were presented. The dangers to today's family as consequences of the ongoing transformation were also indicated.

Keywords: family; alternative forms of family life; family upbringing; social change.

35 W. Bołoz, dz. cyt., s. 11.
36 Tamże. 
